\title{
STRATEGI COPING TERHADAP STRES KERJA DI LINGKUNGAN KARYAWAN STAIN MALANG Tristiadi Ardi Ardani
}

\begin{abstract}
Background: Stres effect of work represent an problems which later will become big problems in the field of safety and health of work Because stres have undesirable impact like for example accident of work, disease related to work and also health of management and mental. Preventive of stres require to be conducted comprehensively good at organizational storey; level and also at individual storey; level and also entangle role various sector and also various professional circlewhich is discipline multi.

Method: Analysis Data of kuantitif in this research of method used analyse dwivariat test student $t$ between program group of SPS 2000 from Sutrisno Hadi and of Yuni Pamardiningsih UGM Version of IBM / in, Copyrights (c) 2002. While with data collecting method qualitative by interview at employees of STAIN Malang.

Result: From result of koputasi obtained by result of higher woman group average of men average with woman group average number equal to 116.000 while its men group [of] him equal to 113.778. From result of test of $t$ which is to be obtained by value of $\mathrm{p}$ equal to 0.504 . There by can be said that by there no different among woman and men in strategy of coping in face of work stres. In this research to know technique reliabilitas taken is analysis of varians of Hoyt. Of computing test by using program of SPS of Sutrsino Hadi and of Yuni Pamardiningsih UGM Version of IBM / in, Copyrights (c) 2002 obtained result of tt $\mathrm{r}$ equal to 0.832 , $\mathrm{p}$ equal to 0.000 meaning the appliance reliabilitas can be pledged. While with data collecting method qualitative by interview at employees obtained by result of that there is indication of is existence of stres work at employees.

Conclusion: that no different between woman and men in strategy of coping in face of work stres. Method data collecting quantitatively with enquette at employees obtained by result of that there is indication of is existence of stres work at employees. As for strategy of coping in face of stres to men employees most chosening to smoke, but there is also employees chosening to walk along to watch television and others when is face work. While at woman employees some people chosen to discuss with friend one friend or office of other office and some of again chosen to walk along when stres face work.
\end{abstract}

Keyword: strategy of coping, stres work.

\section{A. PENDAHULUAN.}

GBHN 1993 menyatakan bahwa titik berat PJP II adalah bidang ekonomi, yaitu terciptanya keseimbangan antara sektor pertanian dan sektor industri. Proses industrialisasi sendiri memerlukan penyediaan sumber daya manusia berkualitas, penerapan ilmu dan teknologi maju dan canggih, disamping persaingan yang 
ketat. Realitas ini tidak dapat dihindari, termasuk juga dalam dunia pendidikan. Perguruan tinggi bersaing ketat untuk memberikan pelayan yang berstandar tinggi dan berkualitas pada mahasiswa. Sekolah Tinggi Agama Islam Negeri (STAIN) Malang, adalah salah saru perguruan tinggi negeri yang terlibat langsung dalam persaingan tersebut. Lembaga ini menyediakan sarana dan prasarana yang lengkap didukung sumber daya yang berkualitas baik, mulai pejabat rektorat, dosen sampai karyawan. Semua dilakukan demi menghadapi persaingan tersebut.

Dalam lingkungan kerja dengan sistem kompleks ini setiap komponen saling berkait. Setiap subsistem saling berirteraksi, seperti bagian administrasi akan berhubungan dengan data dan informasi, bagian kemahasiswaaan berinteraksi dengan bagian perpustakaan. Adanya interaksi antara berbagai komponen dalam lingkungan kerja seperti ini dapat menimbulkan berbagai dampak psikologis. Yang paling utama memegang peranan adalah faktor penjadwalan seperti waktu kerja, masa istirahat dan sebagainya. Kesemuanya penyebab gangguan psikologis yang menimbulkan kelelahan. ${ }^{1}$

Reaksi dari setiap karyawan terhadap lingkungan kerja merupakan reaksi psikologis yang menimbulkan kondisi fisiologis seperti meningginya tekanan darah. Timbulnya ulcus ventriculi, sakit kepala dan beberapa gangguan kesehatan lainnya. Bersamaan dengan ini timbul pula reaksi psikologis berupa ketegangan syaraf, depresi dan lain-lain yang mengganggu keseimbangan kehidupan. Berbagai komponen di lingkungan kerja yang menimbulkan reaksi psikologis maupun fisiologis dikenal sebagai stressor dan aspek gangguan kepribadian terhadap karyawan tersebut di kenal sebagai stres.

Stres merupakan respon adaptif karyawan terhadap situasi dan kejadian di lingkungan kerja dan hal ini berakibatkan tuntutan khusus baik fisik maupun psikologis dari karyawan tersebut. Adanya peringatan maupun resiko terhadap bahaya potensial di lingkungan kerja maka para karyawan berhadapan dengan sindroma fight or flight dimana terbebaskan hormon adrenalin, perubahan pernafasan maupun timbulnya ketegangan otot. Bagi para karyawan yang telah terlatih dan dilengkapi dengan peralatan terhadap bahaya fisik akan berkurang tingkat stres seperti para pekerja tambang, polisi, petugas pemadam kebakaran maupun militer. Untuk ini tentu harus ada suatu stimulus yang memiliki potensi bahaya dan menyangkut persepsi terhadap ancaman yang muncul serta perbandingan antara tuntutan yang menekan individu dan kemampuannya untuk mengatasi tuntutan tersebut. Perilaku ini bisa dikenal sebagai strategi coping.

Beberapa penelitian telah mengungkapkan bahwa beberapa pekerjaan menimbulkan banyak stress related illness. Namun, hal itu bukan berarti semua penyakit disebabkan oleh pekerjaan. Hampir semua orang dalam kehidupan mengalami stress sehubungan dengan pekerjaan mereka. Tidak jarang situasi yang stressful kecil dan tidak berarti tetapi justru memberikan yang besar dan berkelanjutan dalam jangka waktu yang lama. Penelitian sebelumnya menemukan bahwa muatan kerja dapat mempengaruhi terjadinya peningkatan kecelakaan dan masalah-masalah kesehatan, sehingga para karyawan mengalami stress dan akan berupaya bagamana mengatasi stres tersebut.

Setiap individu memberikan reaksi yang berbeda dalam mengatasi stress. Lazarus dan Folkman, menggambarkan coping sebagai,“... Suatu proses di mana 
individu mencoba untuk mengelola jarak yang ada antara tuntutan-tuntutan (baik yang berasal dari individu maupun dari lingkungan) dengan sumber-sumber daya yang mereka gunakan dalam mengatasi situasi stressful...". 2 Artinya, stress dapat diatasi dengan melakukan transaksi dengan lingkungan (perilaku coping) dimana hubungan transaksi ini merupakan suatu proses yang dinamis.

Beranjak dari dasar pemikiran diatas, permasalahan yang akan dikaji secara mendalam pada penelitian ini adalah strategi coping terhadap stress kerja di lingkungan karyawan STAIN Malang.

\section{Tujuan Penelitian.}

Penelitian ini bertujuan untuk mengetahui strategi coping terhadap stres kerja di lingkungan karyawan STAIN Malang

\section{Manfaat Penelitian}

Penelitian ini diharapkan akan membawa manfaat antara lain:

a. Secara teoritis, memberikan tambahan kajian tentang strategi coping terhadap stres. Dan sumbangan buat psikologi klinis yang bisa dimanfaatkan di dunia psikologi industri dan organisasi.

b. Secara praktis, Memberikan tambahan khasanah dan model bagi sebuah instansi atau lembaga, perusahaan yang peduli kesehatan karyawannya.

\section{B. TINJAUAN TEORITIS.}

\section{Strategi Coping}

Secara umum, stress dapat diatasi dengan melakukan transaksi dengan lingkungan (perilaku coping) dimana hubungan transaksi ini merupakan suatu proses yang dinamis. Beberapa ahli menyimpulkan bahwa coping itu adalah,

(a) respons tingkah laku atau pikiran terhadap situasi stres.

(b) dengan menggunakan sumber dalam dirinya maupun lingkungan

(c) yang dilakukan secara sadar dan

(d) bertujuan untuk meningkatkan perkembangan individu seperti pengembangan kontrol pribadi individu. ${ }^{3}$

Secara umum coping itu sendiri mempunyai 2 macam fungsi, yaitu :

(1). Emotion focused coping.

Untuk mengatur respon emosional terhadap stress. Pengaturan ini melalui perilaku individu, seperti penggunaan alkohol, meniadakan fakta-fakta yang tidak menyenangkan, melalui strategi kognitif. Bila individu tidak mampu mengubah kondisi yang stressful, individu akan cenderung untuk mengatur emosinya.

(2) Problem focused coping.

Untuk mengurangi stressor, individu akan mengatasi dengan mempelajari cara-cara atau kerampilan-ketrampilan yang baru. Individu akan cenderung menggunakan strategi ini, bila dirinya yakin akan dapat mengubah situasi. ${ }^{4}$

\section{Stres Kerja.}

Perkembangan ekonomi yang cepat, perampingan perusahaan, PHK, merger dan bangkrutnya beberapa perusahaan sebagai akibat dari krisis yang berkepanjangan telah menimbulkan dampak yang sangat merugikan bagi ribuan bahkan jutaan tenaga kerja. Mereka harus rela dipindahkan kebagian yang sangat tidak mereka kuasai dan tidak tahu berapa lama lagi mereka akan dapat bertahan 
atau dipekerjakan. Selain itu mereka harus menghadapi boss baru, pengawasan yang ketat, tunjangan kesejahteraan berkurang dari sebelumnya, dan harus bekerja lebih lama dan lebih giat demi mempertahankan status sosial ekonomi keluarga. Para pekerja di setiap level mengalami tekanan dan ketidakpastian. Situasi inilah yang seringkali memicu terjadinya stres kerja

Anoraga mendefinisikan stres sebagai suatu bentuk tanggapan seseorang, baik secara fisik maupun mental terhadap suatu perubahan lingkungan yang dirasakan mengganggu dan mengakibatkan dirinya terancam ${ }^{5}$. Sementara itu, Beehr dan Newman mengatakan bahwa stres kerja merupakan suatu interaksi antara kondisi kerja dengan sifat-sifat pekerja yang mengubah fungsi fisik maupun psikis yang normal. Definisi tersebut menunjukkan bahwa stres kerja merupakan tuntutan pekerjaan yang tidak dapat diimbangi oleh kemampuan pekerja. $^{6}$

Pengertian yang sama diungkapkan oleh Riggio yang mengatakan bahwa stres kerja merupakan suatu keadaan yang penuh dengan tekanan yang diakibatkan karena peristiwa dalam lingkungan pekerjaan. ${ }^{7}$ Disisi lain, menurut Berry, stres kerja merupakan respon tubuh yang muncul karena stresor kerja. Pekerjaan-pekerjaan tertentu umumnya dirasakan menjadikan munculnya stres kerja. Stres kerja muncul tergantung pada situasi atau kondisi yang ada. ${ }^{8}$

Stres merupakan suatu kondisi ketegangan yang mempengaruhi emosi, proses berpikir dan kondisi seseorang. Kondisi yang cenderung menimbulkan stres disebut stresor. ${ }^{9}$ Menurut Cary Cooper dan Alison Straw dari British Institute of Manajement, gejala stres dapat dilihat dari tiga sisi, yaitu gejala fisik, tingkah laku secara umum, gejala-gejala di tempat kerja. ${ }^{10}$

Berdasarkan uraian di atas, maka disimpulkan bahwa stres kerja merupakan suatu keadaan yang bersifat potensial maupun nyata yang penuh dengan tekanan dan melibatkan tuntutan fisik serta psikologis yang diakibatkan karena peristiwa atau kondisi dalam lingkungan pekerjaan yang sifatnya relatif karena dipengaruhi oleh penyesuaian diri individu.

Menurut Gibson, Ivancevich dan Donnelly, ada 4 macam penyebab stres kerja, yaitu:

(1) lingkungan fisik.

Sumber stres ini adalah faktor cahaya, suara, suhu, dan udara yang terkena polusi, sehingga biasanya menjadi masalah bagi pekerjaan-pekerjaan kasar

(2) individual.

Terdiri dari konflik peran, ambiguitas peran, beban kerja yang berlebihan, dan tanggungjawab pekerjaan. Konflik peran adalah sumber stres yang akan muncul dan akan semakin meningkat ketika seseorang menerima pesan-pesan yang tidak cocok berkenaan dengan perilaku yang sesuai, misalnya saja adanya tekanan untuk bergaul dengan orang-orang yang tidak sesuai dengan diri seseorang. Ambiguitas peran terjadi ketika tidak adanya pengetahuan seorang individu tentang hak, hak istimewa, dan kewajiban dari suatu pekerjaan.

Beban kerja yang berlebihan bisa berupa beban kerja secara kuantitatif maupun kualitatif. Beban kerja yang bersifat kualitatif dirasakan individu ketika individu merasa tidak memiliki kemampuan yag dibutuhkan untuk 
menyelesaikan pekerjaan atau adanya tuntutan standar performansi kerja yang terlalu tinggi. Beban kerja yang bersifat kumulatif adalah banyaknya sesuatu yang harus dikerjakan atau tidak cukupnya waktu yang diberikan untuk menyelesaikan suatu pekerjaan. Sedangkan tanggungjawab pekerjaan bisa menjadi beban kerja yang dapat menimbulkan stres kerja apabila tanggungjawab tersebut dirasakan terlalu besar bagi individu yang bersangkutan.

(3) struktur organisasi.

Hal-hal yang mengakibatkan kondisi emosional yang negatif adalah jeleknya struktur organisasi, misalnya struktur organisasi yang terlalu panjang, struktur yang terlalu birokratis, atau struktur organisasi yang terlalu kaku, serta tidak adanya kebijakan khusus bagi pekerja ${ }^{11}$.

Sementara itu, Berry berpandangan bahwa stres dalam kerj disebabkan oleh sumber fisik yang berupa tingkat kebisingan, temperatur atau suhu dan polusi udara; kondisi temporal dalam suatu pekerjaan yang meliputi perubahan zona waktu, perubahan jadual dan adanya tenggang waktu atau deadline untuk menyelesaikan suatu pekerjaan; kondisi sosiopsikologis yang terdiri dari tekanan akibat perkawinan, kesesakan serta adanya relokasi atau migrasi; karakteristik pekerjaan yaitu pekerjaan yang berlebihan atau sebaliknya, beban pekerjaan yang sangat ringan, konflik peran serta adanya ambiguitas peran, adanya perubahan dalam organisasi. ${ }^{12}$

Disisi lain, Riggio mengungkapkan bahwa faktor-faktor yang dapat menjadi sumber stres atau stresor kerja adalah,

(1) stresor organisasional.

a) pekerjaan yang berlebihan, dimana stres akan terjadi ketika pekerjaan yang harus dilakukan membutuhkan kerja yang sangat cepat, hasil yang banyak dan konsentrasi yang berlebihan.

b) Under-utilization, yaitu suatu keadaan dimana seorang pekerja merasa tidak dapat menggunakan kemampuan yang dimilikinya yang berhubungan dengan pekerjaan.

Misalnya lulusan sarjana yang bekerja pada bagian costumer service akan merasakan stres karena tidak bisa menggunakan kemampuannya dalam bekerja.

c) Ketidakpastian tugas. Ketidakpastian tugas merupakan sumber stres yang dihasilkan dari ambiguitas tugas pekerjaan. Misalnya saja, tugas dan persyaratannya tidak didefinisikan secara jelas. Ketika pekerja tidak yakin dengan tanggungjawab mereka dan tugas-tugas yang harus dikerjakan, maka stres dapat muncul. Ketidakpastian pekerjaan yang bisa menghasilkan stres ini juga bisa dihasilkan dari kurangya umpan balik reguler terhadap performansi individu yang bersangkutan, seberapa baik atau burukkah hasil kenerja mereka.

d) Kondisi fisik di lingkungan kerja. Kondisi fisik di lingkungan kerja juga merupakan sumber stres. Pekerjaan yang dilakukan pada temperatur yang ekstrem, suara yang bising atau pencahayaan yang kurang atau ventilasi yang terbatas dapat mempengaruhi munculnya stres. Pekerjaan yang 
penuh bahaya yang menempatkan pekerja beada pada resiko kesehatan dan resiko hidup dapat juga menjadi penyebab stres.

(2) Sumber stres yang berdasarkan pada hubungan.

Salah satu sumber paling besar yang membuat stres kerja dihasilkan dari sulitnya hubungan interpersonal pada pekerjaan, yaitu stres interpersonal yang merupakan salah satu tipe stres dimana mungkin hampir semua pekerja mengalaminya. Stres interpersonal dipicu dari kesulitan dalam membangun dan memelihara hubungan dengan pekerja lain dalam bekerja. Pimpinan yang kasar dengan gaya manajemen yang menghukum akan juga menjadi sumber stres. Stres interpersonal juga bisa diakibatkan oleh rekan kerja dimana antara individu dan rekan kerjanya ditempatkan dalam situasi konflik yang serupa. Misalnya adanya promosi atau kenaikan jabatan.

(3) Perasaan kurangnya kontrol.

Perasaan semacam ini umumnya terjadi pada pekerjaan di tingkat rendah sampai pada pekerjaan tingkat tinggi dalam suatu organisasi.

Pekerjaan yang sangat kaku dan penuh dengan aturan dimana pekerja tidak mampu mendapatkan masukan dalam keputusan pekerjaan dan prosedur akan menimbulkan stres, khususnya bagi pekerja yang ingin mendapatkan masukan. Penelitian mengindikasikan bahwa pekerja yang mampu melakukan kontrol terhadap lingkungan pekerjaannya, dengan teknik-teknik seperti memberikan suara dalam proses pengambilan keputusan, akan berkurang stresnya dan meningkat kepuasan kerjanya.

(4) Situasi yang berubah, meliputi: reorganisasi perusahaan, penggabungan dengan organisasi yang lain atau akusisi dengan perusahaan lain, berubahnya sistem kerja dan teknologi kerja, perubahan dalam kebijakan perusahaan, perubahan manajerial atau perubahan personel. ${ }^{13}$

Menurut Terry Beehr dan John Newman gejala stress kerja dapat di bagi dalam 3 (tiga) aspek, yaitu gejala psikologis, gejala psikis dan perilaku.

\begin{tabular}{||l||l||l||}
\hline \hline Gejala Psikologis & Gejala Fisik & Gejala Perilaku \\
\hline \hline Kecemasan, ketegangan & $\begin{array}{l}\text { Meningkatnya detak jantung } \\
\text { dan tekanan darah }\end{array}$ & $\begin{array}{l}\text { Menunda ataupun menghindari } \\
\text { pekerjaan/tugas }\end{array}$ \\
\hline \hline Bingung, marah, sensitif & $\begin{array}{l}\text { Meningkatnya sekresi } \\
\text { adrenalin dan noradrenalin }\end{array}$ & Penurunan prestasi dan produktivitas \\
\hline \hline Memendam perasaan & $\begin{array}{l}\text { Gangguan gastrointestinal, } \\
\text { misalnya gangguan lambung }\end{array}$ & $\begin{array}{l}\text { Meningkatnya penggunaan minuman } \\
\text { keras dan mabuk }\end{array}$ \\
\hline \hline Komunikasi tidak efektif & Mudah terluka & Perilaku sabotase \\
\hline \hline Mengurung diri & Mudah lelah secara fisik & Meningkatnya frekuensi absensi \\
\hline \hline Depresi & Kematian & $\begin{array}{l}\text { Perilaku makan yang tidak normal } \\
\text { kebanyakan atau kekurangan) }\end{array}$ \\
\hline \hline Merasa terasing dan & Gangguan kardiovaskuler & Kehilangan nafsu makan dan \\
\hline \hline
\end{tabular}




\begin{tabular}{|c|c|c|}
\hline mengasingkan diri & & penurunan drastis berat badan \\
\hline Kebosanan & Gangguan pernafasan & $\begin{array}{l}\text { Meningkatnya kecenderungan perilaku } \\
\text { beresiko tinggi, seperti ngebut, berjudi }\end{array}$ \\
\hline Ketidakpuasan kerja & Lebih sering berkeringat & $\begin{array}{l}\text { Meningkatnya agresivitas, dan } \\
\text { kriminalitas }\end{array}$ \\
\hline Lelah mental & Gangguan pada kulit & $\begin{array}{l}\text { Penurunan kualitas hubungan inter- } \\
\text { personal dengan keluarga dan teman }\end{array}$ \\
\hline $\begin{array}{l}\text { Turunnya fungsi } \\
\text { intelektual }\end{array}$ & Kepala pusing, migrain & Kecenderungan bunuh diri \\
\hline $\begin{array}{l}\text { Kehilangan daya } \\
\text { konsentrasi }\end{array}$ & Kanker & \\
\hline $\begin{array}{l}\text { Kehilangan spontanitas } \\
\text { dan kreativitas }\end{array}$ & Ketegangan otot & \\
\hline $\begin{array}{l}\text { Kehilangan semangat } \\
\text { hidup }\end{array}$ & $\begin{array}{l}\text { Probem tidur (sulit tidur, } \\
\text { terlalu banyak tidur) }\end{array}$ & \\
\hline $\begin{array}{l}\text { Menurunnya harga diri } \\
\text { dan rasa percaya diri }\end{array}$ & & \\
\hline
\end{tabular}

Dampak dari stres yang potensial, yaitu:

1. Dampak subyektif, antara lain berupa kekhawatiran atau ketakutan, agresi, apatis, rasa bosan, depresi, keletihan, frustrasi, kehilangan kendali emosi, penghargaan diri yang rendah, gugup, kesepian.

2. Dampak perilaku yang berupa mudah mendapatkan kecelakaan, kecanduan alkohol, penyalahgunaan obat, makan atau merokok secara berlebihan, perilaku impulsif.

3. Dampak kognitif dapat berupa ketidakmampuan untuk membuat keputusan yang masuk akal, daya konsentrasi rendah, kurang perhatian, sangat sensitif terhadap kritik, hambatan mental.

4. Dampak fisiologis dapat berupa kandungan glukosa darah meningkat, denyut jantung, tekanan darah meningkat, berkeringat, mulut kering, bola mata melebar, tubuh panas dan dingin.

5. Dampak organisasi antara lain berupa angka absensi rendah, omset rendah, produktifitas rendah, terasing dari mitra kerja, ketidakpuasan kerja, komitmen organisasi dan loyalitas berkurang. ${ }^{14}$

Akibat timbulnya stres adalah terjadinya pergeseran faktor psikologis maupun fisik diluar keseimbangan (stabilitas). Mekanisme ini tergambar pada diagram berikut: 


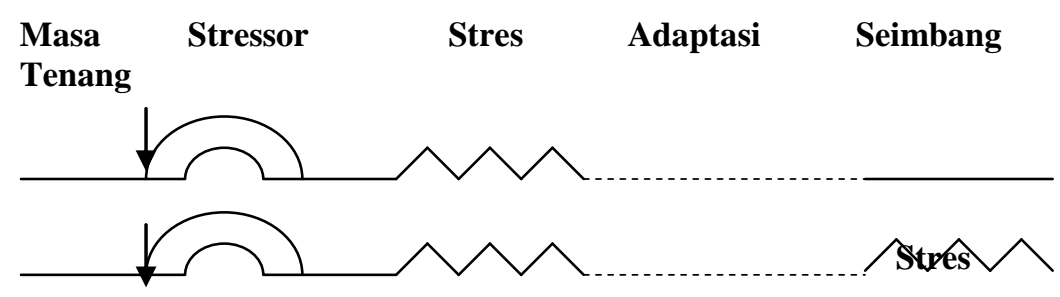

Dalam melakukan suatu pekerjaan karyawan akan mengalami stres. Stres merupakan suatu respon adaftif karyawan terhadap situasi dan kejadian di lingkungan kerja. Stres bisa positif atau negatif. Jika stres itu negatif maka karyawan akan mengadakan adaptasi coping sehinggga keadaan menjadi Hipotesis. seimbang seperti semula.

Berdasarkan uraian di atas, hipotesis yang diajukan penelitian ini adalah ada perbedaan antara laki-laki dan perempuan di lingkungan karyawan STAIN Malang dalam memilih strategi coping terhadap stres.

\section{METODE PENELITIAN.}

\section{Variabel Penelitian.}

Untuk meneliti suatu konsep secara empiris, konsep tersebut harus dioperasionalkan dengan mengubahnya menjadi variabel. Variabel adalah segala sesuatu yang menjadi obyek pengamatan penelitian atau faktor-faktor yang berperan dalam peristiwa atau gejala yang diteliti. Dalam penelitian ini variabel yang diteliti meliputi variabel bebas dan terikat, yaitu:

a. Variabel Bebas : Strategi coping

b. Variabel Terikat : Stres Kerja

\section{Definisi Opeasional.} berikut:

Definisi operaional dari variabel-variabel dalam penelitian adalah sebagai

a. Strategi coping terhadap stres.

Suatu proses di mana individu mencoba untuk mengelola jarak yang ada antara tuntutan-tuntutan (baik tuntutan yang berasal dari individu maupun tutntutan yang berasal dari lingkungan) dengan sumber-sumber daya yang mereka gunakan dalam mengatasi situasi stressful.

b. Stress kerja.

Stres kerja merupakan suatu keadaan yang bersifat potensial maupun nyata yang penuh dengan tekanan dan melibatkan tuntutan fisik serta psikologis yang diakibatkan karena peristiwa atau kondisi dalam lingkungan pekerjaan yang sifatnya relatif karena dipengaruhi oleh penyesuaian diri individu.

\section{Populasi dan Sampel.}

Populasi yang digunakan, sesuai tujuan penelitian ini, adalah seluruh karyawan di lingkungan STAIN Malang. Pengambilan subyek sebagai sampel penelitian ini dilakukan dengan mempertimbangkan ciri-ciri populasi yang telah disebutkan sebelumnya, yaitu:

1. Karyawan di lingkungan STAIN Malang

2. Pendidikan minimal SMA 
3. Berjenis kelamin laki-laki atau perempuan

4. Selama penelitian berdomisili di Malang

Metode Pengumpulan Data.

Data dikumpulkan dengan menggunakan beberapa metode:

a. Observasi, dilakukan dengan cara mengamati pelaksanaan pelayanan kerja di lingkungan STAIN Malang dan bagaimana strategi karyawan dalam menghadapi stres kerja.

b. Wawancara, dilakukan untuk menggali data yang lebih mendalam tentang pelaksanaan kerja di lingkungan STAIN Malang dan bagaimana strategi karyawan dalam menghadapi stres kerja.

c. Kuesioner. Dalam penelitian ini digunakan satu macam angket yaitu angket yang mengukur tentang strategi coping terhadap stres. Metode angket digunakan dengan alasan bahwa subjek adalah orang yang paling tahu tentang dirinya. Apa yang dikemukakan oleh subjek dianggap benar dan dapat dipercaya, dan interpretasi subjek tentng pernyataan-pernytaan yang diajukan kepadanya adalah sama dengan apa yang dimaksud oleh pembuat skala.

d. Angket Identitas Diri. Digunakan untuk mengetahui data-data pribadi dari subjek, seperti jenis kelamin, umur, pendidikan terakhir, dan lain-lain.

\section{Metode Analisis Data}

Data dari hasil penelitian yang dikumpulkan melalui skala yang sudah diuji kesahihan dan keandalannya dianalisis dengan menggunakan uji $t$ dan dengan mempertimbangkan rerata untuk tiap-tiap kelompok. Dalam penelitian ini seluruh hasil perhitungan analisis dilakukan dengan menggunakan Seri Program Statistik (SPS) -2000 edisi Sutrisno Hadi dan Yuni Pamardiningsih UGM Versi IBM/IN, Hak Cipta (c) 2002. ${ }^{15}$

\section{TEMUAN PENELITIAN.}

\section{Lokasi Penelitian.}

Penelitian ini dilakukan di STAIN Malang dengan populasi karyawan di lingkungan lembaga tersebut. Alasan dipilihnya STAIN Malang sebagai lokasi penelitian adalah karena STAIN Malang adalah perguruan tinggi yang sedang menanjak dan sedang menata diri. Dengan makin pesatnya perkembangan STAIN Malang dan bertambah banyaknya jumlah mahasiswa berarti makin menuntut pelayanan yang baik. Pelayanan yang makin baik dan banyak tetapi tidak diimbangi dengan jumlah karyawan akan mengakibatkan resiko stres kerja yang tinggi. Untuk itulah peneliti memilih STAIN Malang sebagai lokasi penelitian.

Penelitian dari dilakukan tanggal 1 Agustus - 15 September 2002 dengan jumlah sampel sebanyak 28 orang karyawan. Dari 40 angket yang disebarkan 5 buah angket tidak dikembalikan dengan lengkap, 2 angket tidak diisi lengkap identitasnya, 5 angket tidak lengkap jawabannya, dan sisanya adalah angket dari karyawan yang bisa dianalisa. Selain itu, pengumpulan data juga dilakukan dengan mengunakan metode kualitatif terutama untuk mengetahui data dari karyawan mengenai strategi coping terhadap stres kerja dengan memberi pertanyaan-pertanyaan yang berkaitan dengan stres kerja dan bagaimana cara mengatasinya.. 
Sebelumnya peneliti mengadakan observasi lapangan, untuk mencari dan menemukan informan yang tepat sesuai dengan syarat- syarat sebagai informan yang telah ditentukan sebelumnya.

\section{Validitas Alat Ukur.}

Hasil komputasi analisis kesahihan butir (validity) dengan menggunakan program SPS dari Sutrisno Hadi dan Yuni Pamardiningsih UGM Versi IBM/IN, Hak Cipta (c) 2002 menyatakan bahwa dari 40 butir, 20 butir gugur sedangkan 20 butir sahih. Adapun butir yang gugur adalah butir nomor 1, 2,3,4, 7, 8, 10, 11, 12, $14,18,19,21,26,2728,34,36,37,38$ s

\section{Reliabilitas.}

Reliabilitas teknik yang dilakukan adalah analisis varians dari Hoyt. Dari uji komputasi dengan menggunakan program SPS dari Sutrsino Hadi dan Yuni Pamardiningsih UGM Versi IBM/IN, Hak Cipta (c) 2002 diperoleh hasil $r$ tt sebesar 0.832 , p sebesar 0.000 yang berarti reliabilitas alat tersebut dapat diandalkan.

\section{Analisa Data.}

Analisis data kuantitif dalam penelitian ini mengunakan metode analisis dwivariat uji t student antar kelompok program SPS 2000 dari Sutrisno Hadi dan Yuni Pamardiningsih UGM Versi IBM/IN, Hak Cipta (c) 2002. Dari hasil koputasi diperoleh hasil rerata kelompok wanita lebih tinggi dari rerata laki-laki dengan angka rerata kelompok wanita sebesar 116.000 sedangkan kelompok lakilaki reratanya sebesar 113.778 .

Dari hasil uji t yang dilakukan diperoleh nilai p sebesar 0.504. Dengan demikian dapat dikatakan bahwa tidak ada perbedaaan antara laki-laki dan wanita dalam strategi coping dalam menghadapi stres kerja. Sedang dengan metode pengumpulan data secara kualitatif dengan cara wawancara pada karyawan diperoleh hasil bahwa ada indikasi adanya stres kerja pada karyawan. Adapun strategi coping dalam menghadapi stres bagi karyawan laki-laki sebagian besar adalah merokok, berjalan-jalan dan menonton televisi, sedang pada karyawan wanita memilih untuk berbincang-bincang dengan teman satu kantor atau teman dari kantor yang lain dan sebagian lagi memilih untuk berjalan-jalan.

\section{E. P E N U T U P \\ Kesimpulan.}

Hasil komputasi yang menggunakan program SPS 2000 dari Sutrisno Hadi dan Yuni Pamardiningsih UGM Versi IBM/IN, Hak Cipta (c) 2002 diperoleh hasil p sebesar 0.504. dengan demikian dapat dikatakan bahwa tidak ada perbedaaan antara laki-laki dan wanita dalam strategi coping dalam menghadapi stres kerja. Sementara itu, dengan metode pengumpulan data secara kualitatif dengan cara wawancara pada karyawan diperoleh hasil bahwa ada indikasi adanya stres kerja pada karyawan. Adapun strategi coping dalam menghadapi stres bagi karyawan laki-laki sebagian besar memilih merokok, berjalan-jalan atau menonton televisi, sedang pada karyawan wanita memilih untuk berbincang-bincang dengan teman satu kantor atau teman dari kantor yang lain, atau memilih untuk berjalan-jalan.

Stres akibat kerja merupakan permasalahan yang besar dalam bidang keselamatan dan kesehatan kerja, karena stres mempunyai dampak yang tidak 
diinginkan seperti kecelakaan kerja, penyakit yang berhubungan dengan pekerjaan serta kesehatan mental. Pencegahan dan manajemen stres perlu dilakukan secara komprehensif baik pada tingkat organisasi maupun pada tingkat individu serta melibatkan peran berbagai sektor maupun berbagai kalangan profesional yang multi disiplin.

\section{Saran-saran.}

1. Bagi para peneliti berikutnya yang berminat terhadap tema yang sama, hendaknya mempertimbangkan variable-variabel lain yang mempengaruhi strategi coping terhadap stres seperti perbedaan beban kerja, lingkungan kerja, jenis pekerjaan, dan lain-lain.

2. Bagi para pengambil keputusan,

a. agar mempertimbangkan faktor-faktor yang mempengaruhi stres kerja pada karyawan sehingga diperoleh hasil yang kerja yang optimal.

b. melakukan beberapa program pencegahan dan manajemen untuk memperkecil resiko karyawan mengalami stres kerja melalui beberapa upaya:

- upaya primer: pengembangan aspek organisasi dan aspek pekerjaan dalam rangka memperkecil stresor atau pengendalian hazard (hazard control) khususnya hazard psikososial agar tercapai organisasi yang sehat (health organization).

- upaya sekunder: pelatihan sumber daya manusia dalam konteks promosi kesehatan dan pengembangan skill.

- upaya tertier: pengembangan bantuan konseling pada karyawan.

\section{Catatan Akhir.}

${ }^{1}$ Smet, B. Psikologi Kesehatan. (Jakarta, Grasindo, 1994),

${ }^{2} \mathrm{Ibid}, 4$.

${ }^{3}$ Shinta, E. "Perilaku Coping dan Dukungan Sosial pada pemuda penganggur: Studi Deskriftif terhadap Pemuda Penganggur di Perkotaan, Jurnal Psikologi Indonesia. (edisi No. 1, 1995), 34-42

${ }^{4}$ Ibid, 4.

${ }^{5}$ Anoraga, P. Psikologi Kerja. (Jakarta, Rineka Cipta, 1992),

${ }^{6}$ Rice, P.L. It Resh and Health. (California, Cole Publishing Company, 1992),

${ }^{7}$ Riggio, E. R. Introduction to Industrial/Organizational Psychology, (London, Scott. Glenview, 1990),

${ }^{8}$ Berry, M. L. Psychology at Work. (Mc Graw Hill, 1998),

${ }^{9}$ Umar, H. Sumber Daya Manusia Dalam Organisasi. (Jakarta, Gramedia, 2000),

${ }^{10}$ Ibid, 6.

${ }^{11}$ Gibson, Organizations, (Richard Irwin, Inc, 1995),

${ }^{12}$ Berry, Psychology at Work, (Mc Graw Hill, 1998),

${ }^{13}$ Ibid, 6.

${ }^{14}$ Ibid

${ }^{15}$ Hadi, S \& Pamardiningsih, Seri Program Statistik (2000),

\section{DAFTAR PUSTAKA}


Anoraga, P. Psikologi Kerja. (Jakarta, Rineka Cipta, 1992),

Berry, Psychology at Work, (Mc Graw Hill, 1998),

Gibson, Organizations, (Richard Irwin, Inc, 1995),

Hadi, S \& Pamardiningsih, Seri Program Statistik (2000),

Rice, P.L. It Resh and Health. (California, Cole Publishing Company, 1992),

Riggio, E. R. Introduction to Industrial/Organizational Psychology, (London, Scott Glenview, 1990)

Shinta, E. "Perilaku Coping dan Dukungan Sosial pada pemuda penganggur: Studi Deskriftif terhadap Pemuda Penganggur di Perkotaan, Jurnal Psikologi Indonesia. (edisi No. 1, 1995),

Smet, B. Psikologi Kesehatan. (Jakarta, Grasindo, 1994),

Umar, H. Sumber Daya Manusia Dalam Organisasi. (Jakarta, Gramedia, 2000), 